\title{
Peperite in China and their constraints to tectonics
}

\author{
ZHAOJIE GUO ${ }^{1}$ \\ ${ }^{1}$ School of Earth and Space Sciences, Peking University, \\ Beijing, 100871, China
}

Peperites are special kinds of volcaniclastic materials generated by mingling of magma and unconsolidated sediments. We found several typical classic observations of peperite in China and used them in to researches of key tectonic issues of China.

We found peperites in the Emeishan Large Igneous Provinces (ELIP) and the Tarim Large Igneous Provinces (TLIP) in China. In central zone of Emeishan LIP, we identified two kinds of peperites which are respectively hosted by limestone and palagonitized lapilli tuff in the lower sequences. They demonstrated the central volcanisms of Emeishan were set in a marine depositional environment and therefore have no uplifted effected induced by mantle plume. In the Tarim LIP, the peperites we found is hosted by limestone, implied that the Early Permian in North Tarim was not completely terrestrial. During the period of Tarim LIP eruption, the North Tarim might witnessed frequent transgression and retrogression.

West Junggar in NW China is a key area for the reconstruction of the evolutionary history of the The Central Asian Orogenic Belt (CAOB). Late Paleozoic peperites have been identified in the Darbut and Baijiantan ophiolitic belts at West Junggar. The peperites form successions up to $500 \mathrm{~m}$ thick interbedded with basaltic lava (sometimes pillow lava) and sedimentary rocks (i.e. limestones), and the peperitebearing units are distributed regionally over a distance of 100 $\mathrm{km}$ on either side of the Darbut and Baijiantan ophiolitic belts, in contrast to the highly deformed slices of ophiolite. They demonstrate that the Darbut and Baijiantan ophiolitic belts should not be interpreted as significant plate boundaries and represent the underlying ocean crust uplifted along tectonic lineaments within a continuous shallow remnant ocean basin. A Late Carboniferous volcano-sedimentary complex outcrops on the southwestern flank of the Bogda Mountains, NW China. Discovery of peperites and stratigraphic transitions of the related lithofacies indicate a progressively deepening subaqueous environment, resembling a volcanic evolution from early stage of eruption at a shallower level to increasingly subsiding basin with increasing eruption frequency of basaltic lava at greater water depth. 